\title{
Carotenoids, Flavonoids, Total Phenolic Compounds Content and Antioxidant Activity of Indigenous Pyracantha coccinea M. Roem. Fruits
}

\author{
DAN RAZVAN POPOVICIU ${ }^{1}$, TICUTA NEGREANU-PIRJOL ${ }^{2 *}$, LUDMILA MOTELICA ${ }^{3}$, \\ BOGDAN-STEFAN NEGREANU-PIRJOL ${ }^{2}$ \\ ${ }^{1}$ Ovidius University of Constanta, Faculty of Natural Sciences and Agricultural Sciences, 1 University Alley, Campus, \\ Corp B, 900470, Constanta, Romania \\ ${ }^{2}$ Ovidius University of Constanta, Faculty of Pharmacy, 1 University Alley, Campus, Corp B, 900470, Constanta, Romania \\ ${ }^{3}$ University Politehnica of Bucharest, Faculty of Applied Chemistry and Materials Science, 1-7 Gh. Polizu Str.011061, \\ Bucharest, Romania
}

\begin{abstract}
Scarlet/red firethorn, Pyracantha coccinea M. Roem., is a common ornamental shrub, commonly cultivated nowadays in Romania and many other countries, in gardens or hedges. The tree has small white flowers and it produces small bright colored berries. The fruit is bitter and astringent, making it inedible when raw. The fruit can be cooked to make jellies, jams, sauces and marmalade. In this study, the Pyracantha coccinea $M$. Roem fruits from three common cultivars named „Orange Glow”, ,Red Column” and ,Soleil d'Or”, were collected from different individuals in Constanta city, Romania. Both frozen and dried $\left(80^{\circ} \mathrm{C}\right)$ fruits were analyzed for the active principles content such as, carotenoids, flavonoids and total phenolic compounds correlated with antioxidant activity. Carotenoids were determined by acetone extraction and UV-Vis spectrophotometry, flavonoids, by methanol extraction and UV-Vis spectrophotometry and total phenolic, by methanol extraction, FolinCiocalteu reaction and UV-Vis spectrophotometry. The total antioxidant capacity was quantified through photochemiluminescence method by comparison with the standard substance used for calibration, Trolox ${ }^{\circledR}$ as tocopherol analogue (ACL procedure) using Photochem apparatus, Analytik Jena AG, Germany. The average carotenoid content in fresh frozen fruits ranged between 278-545 $\mathrm{mg} / \mathrm{kg}$ (dry weight equivalent), while in dry material 133-203 mg/kg. Total flavonoids averaged 1415 $4953 \mathrm{mg} / \mathrm{kg}$ in fresh fruits, increasing after heat-drying to $2981-5759 \mathrm{mg} / \mathrm{kg}$. Fresh fruits contained a total amount of phenolic compounds of 11501-21107 mg/kg DW gallic acid equivalent, while dry fruits averaged 5749-8261 mg/kg GAE. Pyracantha coccinea M. Roem. fruits emphasized an increased antioxidant activity correlated with a high content of potentially bioactive compounds, especially of phenolic compounds, both in frozen and heat-dried state. „Red Column” and „Orange Glow” are the most promising varieties of the three cultivars, for potential pharmaceutical applications.
\end{abstract}

Keywords: Pyracantha coccinea, carotenoids, flavonoids, polyphenols, antioxidant activity

\section{Introduction}

Pyracantha (firethorn) is a genus belonging to the Rosaceae family (Amygdaloideae subfamily, Maleae tribe), with several species and hybrids distributed throughout Eurasia. Similar to Cotoneaster pyracantha (L.) Spach, but thorny, some of its species are cultivated as ornamental plants, for gardens, parks or hedges. Pyracantha coccinea M. Roem. (Scarlet firethorn) is the only one native to Western Eurasia (Anatolia, Crimea, Caucasus and Southern Europe) but also is cultivated in Romania.

It is an evergreen shrub, up to $3 \mathrm{~m}$ high, with multiple trunks and sharp leafless thorns, distributed throughout the stem and branches. Leaves are elliptic to lanceolate, 2-4 cm long, with crenate-serrate margins. Small $(8 \mathrm{~mm})$, white flowers are grouped in corymbs and blossom from April to June. Fruits ripen in September; they are small (5-7) mm, globosely pomes. Mature pomes can have various shades of yellow, orange or red, depending on the variety/cultivar. It is resistant to drought, frost, pests and a wide range of soils [1]. In Romania, several cultivars are majority grown for ornamental purposes.

*email: ticuta_np@yahoo.com 
Fruits are bitter and seeds contain hydrogen cyanide. While firethorn fruits are usually not eaten raw, they can be used for marmalade, jams, jellies or various sauces. Due to their tonic, cardiotonic and diuretic properties, it can also be used in folk medicine [2]. Its close relative, Pyracantha crenulata, is a widely used as medicinal plant in China and the Himalayas, its fruits having various uses against anorexia, anxiety, arteriosclerosis, burns, cardiac failure, dysentery, insomnia, hypertension, joint pains, myocardial debility, neurasthenia and tachycardia [3].

The purpose of this paper was to determine the concentration of several classes of key bioactive compounds into indigenous ornamental Pyracantha coccinea M. Roem. shrubs, such as, carotenoids and phenolic/polyphenolic compounds.

Carotenoids (carotenes, lycopene, lutein, zeaxanthin etc.) are common plant pigments. Some are precursors to retinol and melanin (thus, necessary for eye and skin health). Some can also have antitumor properties [4]. In plants, phenolic compounds can serve as pigments and photoprotectors, or offer protection against phytopathogens and insects [5]. They include flavonoids, phenolic acids and tannins. All these can act as antioxidants, through radical scavenging, lipid oxidation inhibition, or reducing activity [6]. Flavonoids (low mass polyphenolic compounds) have antiviral, antibacterial, antifungal, anti-inflammatory, antiproliferative, antitumor properties [5].

\section{Materials and methods}

Firethorn mature fruits of Pyracantha coccinea M. Roem., were collected from various areas (gardens and hedges) in Constanța area, Romania, in October-November 2018 period and kept frozen at $-20{ }^{\circ} \mathrm{C}$. The three most common ornamental cultivars found in Romania, were analyzed: „Orange Glow” (with orange-colored fruits), „Red Column” (red fruits) and „Soleil d'Or” (yellow fruits), Figure 1.

Fruit pyrenes were eliminated by manual means and fruits tissue was ground in an electrical grinder. Part of the fruits pulp tissue was analyzed in its fresh frozen state and the rest was oven-dried, for over $72 \mathrm{~h}$ at $80{ }^{\circ} \mathrm{C}$, before analysis.

Fruits pulp tissue was analyzed for total carotenoids, flavonoids and total phenolic content correlated with antioxidant activity, in triplicate samples for each determination
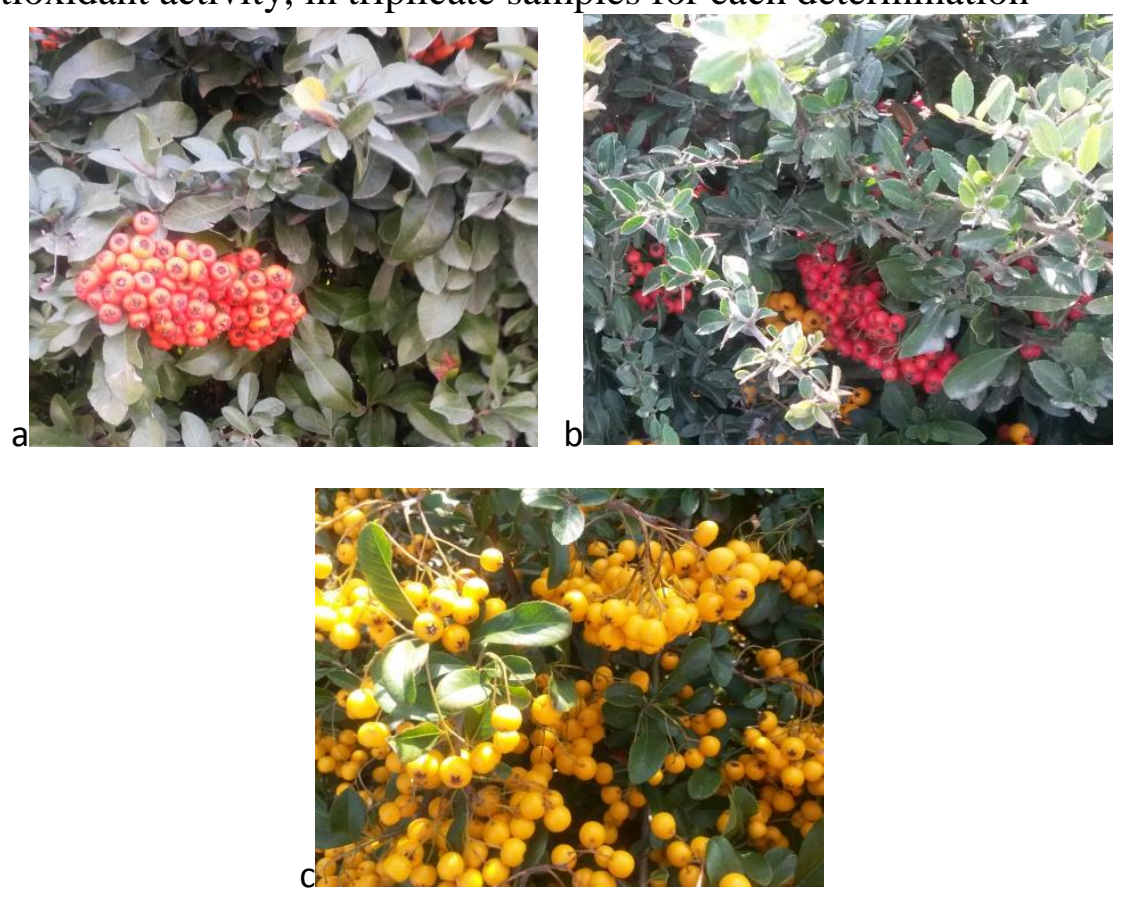

Figure 1. Pyracantha coccinea $\mathrm{M}$. Roem. mature fruits in three cultivars:

a) „Orange Glow”; b) „Red Column”; c) „Soleil d'Or” 
For total carotenoids determining, $0.1 \mathrm{~g}$ of fruits pulp were ground in $10 \mathrm{~mL} 80 \%$ acetone and filtered at normal pressure through Whatman blue band filter paper. The spectrophotometric absorbance was read, using a S106 WPA UV-Vis spectrophotometer, at $470 \mathrm{~nm}, 647 \mathrm{~nm}$ and $663 \mathrm{~nm}$ wavelengths [7]. Pigments concentration was calculated using specific trichromatic equations [8].

For determining flavonoid compounds, $1 \mathrm{~g}$ fruit pulp was ground with $5 \mathrm{~mL}$ methanol and filtered. $0.5 \mathrm{~mL}$ of the resulting extract was diluted in $8 \mathrm{~mL}$ methanol and $4 \mathrm{~mL}$ distilled water. The spectrophotometric absorbance was read at $340 \mathrm{~nm}$ wavelength, against a blank [9].

A spectrophotometric version of the Folin-Ciocâlteu method was used for total phenolic content. $0.1 \mathrm{~g}$ tissue was ground with $10 \mathrm{~mL}$ methanol and filtered. $1 \mathrm{~mL}$ of resulting extract was added to 5 $\mathrm{mL}$ Folin-Ciocalteu reagent $(10 \%)$ and $4 \mathrm{~mL}$ sodium bicarbonate $(7,5 \%)$ and let $30 \mathrm{~min}$ to react. Absorbance was read at $765 \mathrm{~nm}$ wavelength against a blank $[10,11]$. Concentrations were expressed as $\mathrm{mg} / \mathrm{kg}$ dry weight, after fruit dry biomass proportion was determined by oven-drying at $80{ }^{\circ} \mathrm{C}$. Total phenolic content, was expressed as $\mathrm{mg} / \mathrm{kg}$ Gallic acid equivalent (GAE), after method calibration with different gallic acid concentrations.

For total antioxidant capacity determination, well-dried fruits were ground, triturated to fine powder, then a cold extracted by placing $1 \mathrm{~g}$ and of dry vegetable raw material, in volumetric flasks $(100 \mathrm{~mL})$ and making up to the mark with $40 \%$ ethyl alcohol. Extraction was performed for 12 days, at room temperature, at darkness, with regular shaking. Mixtures decanted and normal pressure filtration applied. Resulting 1\% hydroalcoholic extracts were rapidly homogenized using a Vortex Velp Scientifica, Italy agitator and $10 \mu \mathrm{L}$ volume of the sample were taken from the supernatant. Each determination lasted 120 seconds.

The photochemiluminescence method by ACL (Antioxidative Capacity in Lipid Soluble Substances) procedure Analytik Jena and Photochem apparatus Analytik Jena AG, Germany, were used. Triplicate samples of hydroalcoholic extracts were quantified by comparison with the standard substance Trolox $®$, Hoffman-LaRoche's trade name (6-hydroxy-2,5,7,8-tetramethylchroman-2carboxylic acid) vitamin E derivative.

For the calibration curve (Figure 2), standard reagents kit, Analytik Jena Germany was used: $\mathrm{R}_{1}$ (dilution solvent), $\mathrm{R}_{2}$ (buffer reagent), $\mathrm{R}_{3}$ (photosensitive reagent), $\mathrm{R}_{4}$ (reagent sized). The calibration curve was done by measuring a series of standard solutions containing 0.5, 1.0, 2.0, $3.0 \mathrm{nmol}$ Trolox (suitable for 5 - $30 \mu \mathrm{L} \mathrm{R}_{4}$ ). Exposure to external radiation from a Hg lamp lined with phosphorous that provides the maximum energy at $351 \mathrm{~nm}$ wavelength, photosensitive reagent, produces free radicals in the sample for analysis, resulting a photochemical reaction. The free radicals (superoxide anion radicals) produced by optical excitation of a photosensitized substance added in standardized volumes, are partially eliminated by reaction with the antioxidants present in the sample. The residual radicals cause luminescence in the detector substance, which determined by means of a photomultiplier tube. The measuring signal produced by the luminescence is traced over $3 \mathrm{~min}$. The total antioxidant capacity of the sample is measured by converting the electrical signal o concentration values and is quantified by comparison with the standard Trolox ${ }^{\circledR}$ expressed as Trolox equivalency nmol/sample volume $[12,25,26]$. From hydroalcoholic extracts stock solution, samples were prepared, as follows in Table 1.

Table 1. Working scheme volumes, $\mu \mathrm{L}[21,22]$

\begin{tabular}{cccccc}
\hline Kit reagent & $\mathrm{R}_{1}$ & $\mathrm{R}_{2}$ & $\mathrm{R}_{3}$ & $\mathrm{R}_{4}$ & Sample \\
\hline Blank & 2300 & 200 & 25 & 0 & 0 \\
\hline Calibration curve & $2300-$ vol. & 200 & 25 & vol. & 0 \\
\hline Measurement sample & $2300-$ vol. & 200 & 25 & 0 & vol. \\
\hline
\end{tabular}






Figure 2. Calibration curve for standard substance Trolox ${ }^{\circledR}($ ACL method, Analytik Jena AG)

\section{Results and discussions}

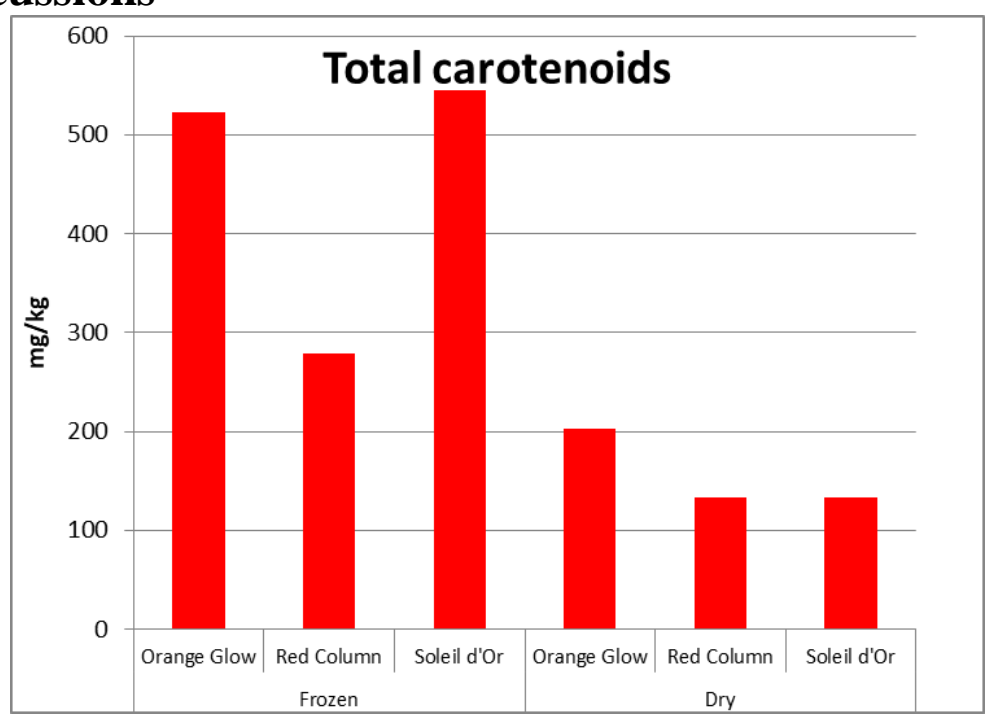

Figure 3. Average concentration of total carotenoid pigments in frozen and dried of Pyracantha coccinea M. Roem. fruits

Figures 3-5 emphasize the concentrations of total extractable carotenoids, flavonoids and phenolic compounds in frozen and heat-dried firethorn fruits. 


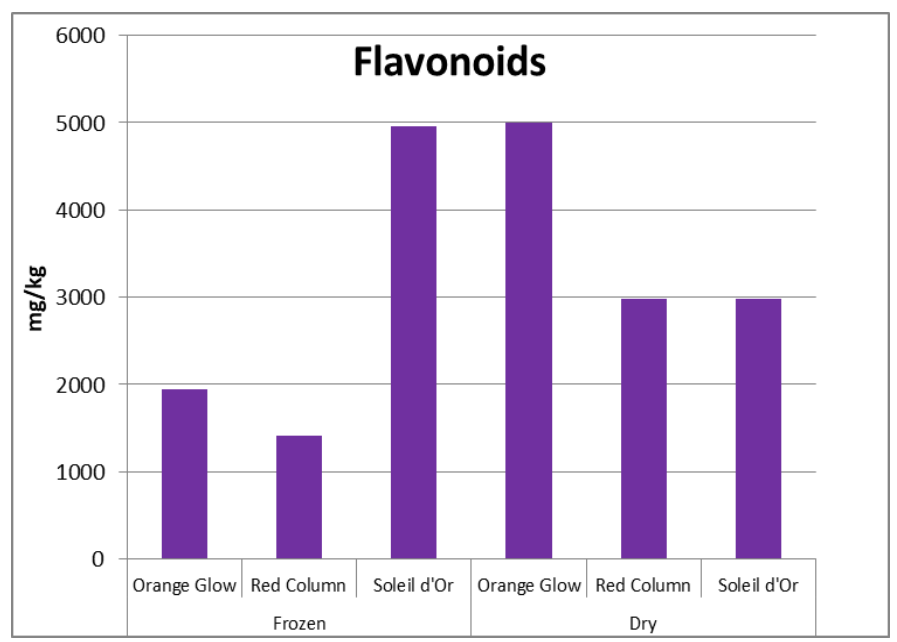

Figure 4. Average concentration of total flavonoid compounds in frozen and dried of Pyracantha coccinea M. Roem. Fruits

Total carotenoids ranged between $278-545 \mathrm{mg} / \mathrm{kg}$ dry weight $(60-92 \mathrm{mg} / \mathrm{kg}$ fresh weight), with the highest values in ,Soleil d'Or”. Heat drying led to a decrease, to $133-203 \mathrm{mg} / \mathrm{kg}$, with the highest content in „Orange Glow” fruits (Figure 3).

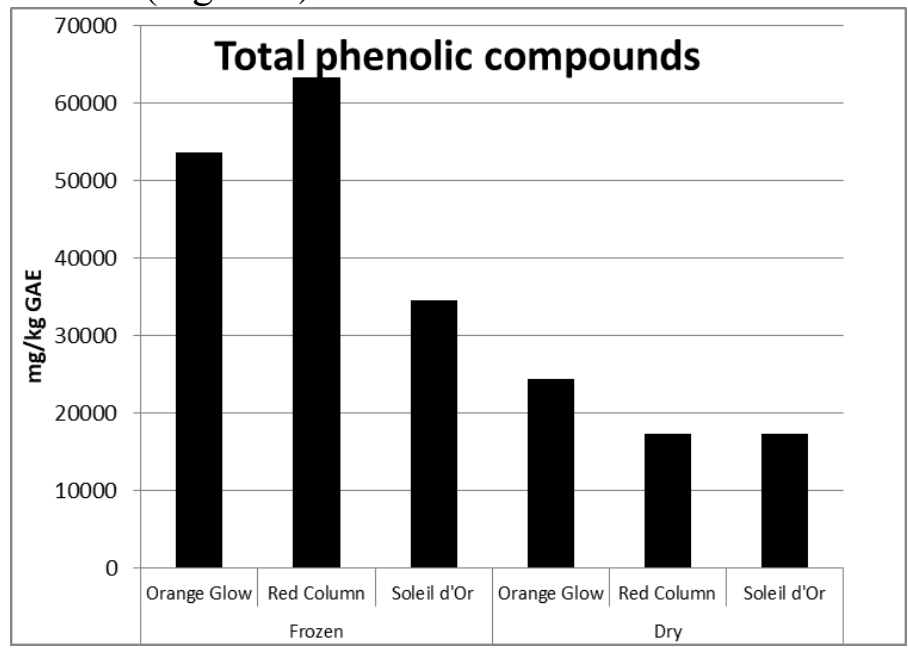

Figure 5. Average concentration of total phenolic compounds in frozen and dried of Pyracantha coccinea M. Roem. fruits

Few studies have been made on carotenoids of Pyracantha berries. A classical study on Pyracantha angustifolia quantified $28 \mathrm{mg} / \mathrm{kg}$ DW pro- $\gamma$-carotene, $28 \mathrm{mg} / \mathrm{kg}$ prolycopene and an additional $7 \mathrm{mg} / \mathrm{kg}$ prolycopene stereoisomer [13]. Pyracantha crenulata would contain $17 \mathrm{mg} / \mathrm{kg}$ lycopene, $5 \mathrm{mg} / \mathrm{kg} \beta$-carotene, plus other carotenoids [14].

Among the close relatives of firethorns are cultivated rowans and service trees (Sorbus sp.). A study on different rowanberry cultivars found from 39 to $2659 \mathrm{mg} / \mathrm{kg}$ total carotenoids (23 - 1262 $\mathrm{mg} / \mathrm{kg} \beta$-carotene), with variations dependent on cultivar, soil, geographical location [6]. These values are comparable to those found in Pyracantha coccinea M. Roem. fruits.

The drop in carotenoids caused by heat-drying varied between $40-76 \%$ (maximum in ,Soleil d'Or"). Experiments have shown that freezing fresh fruit tissue maintains pigment levels close to initial ones, while drying and freeze-drying, can lead to various decreases, depending on species and pigment $[15,16]$.

Total flavonoids had a particular behaviour under freezing/drying conditions. Fresh frozen fruits had 1415 - $4954 \mathrm{mg} / \mathrm{kg}$ concentrations in frozen fruits $(221-991 \mathrm{mg} / \mathrm{kg} \mathrm{FW}$; maximum values in 
„Soleil d'Or” cultivar). Heat-drying caused a drop in flavonoids for „Soleil d'Or” fruits (2981 mg/kg), while in the others enhanced flavonoid synthesis (Figure 4), up to $5759 \mathrm{mg} / \mathrm{kg}$ („Red Column”).

While flavonoid content in Pyracantha was less studied, some data are available from related genera, like Cotoneaster sp. The literature mention that Cotoneaster horizontalis would contain 6800 $\mathrm{mg} / \mathrm{kg}$ [17], while Cotoneaster multiflorus fruit contain up to $53700 \mathrm{mg} / \mathrm{kg} \mathrm{DW}$ flavonoids (amount highly dependent on solvents used) [18-22].

Depending on cultivar and ripening stage, fruits from cultivated rowans and service trees (Sorbus sp.) contain $435-37000 \mathrm{mg} / \mathrm{kg}[6,23]$.

Concerning the behaviour of flavonoids under drying, a research on common fruit anthocyanins showed that the overall concentration might increase or drop significantly after heating, freezing and drying, depending on species and compound type [16,32].

Flavonoids (especially anthocyanins) are potent antioxidants, efficient against diabetes, dislipidemia, inflammation, obesity, or even viral infections [6, 23].

The concentration of overall phenolic and polyphenolic compounds (including flavonoids) ranged between 34502 - $63320 \mathrm{GAE} \mathrm{mg} / \mathrm{kg}$ DW (6900 - $12664 \mathrm{mg} / \mathrm{kg}$ GAE FW), with maximum values in „Red Column” fruits (Figure 5).

These values are higher than those found in Pyracantha crenulata, $7430 \mathrm{mg} / \mathrm{kg}$ [14]. For comparison, $14000 \mathrm{mg} / \mathrm{kg}$ total phenolics were found in Cotoneaster horizontalis [17] and 38600 $\mathrm{mg} / \mathrm{kg}$ in Cotoneaster multiflorus [18]. A quantity of $362-8142 \mathrm{mg} / \mathrm{kg}$ was found in lyophilized rowan fruits [6], $10000-100000 \mathrm{mg} / \mathrm{kg}$ was found in Sorbus domestica (highest values in immature fruits) [23] and $2218-9843 \mathrm{mg} / \mathrm{kg}$ in various wild Sorbus species [24].

Another study on Sorbus torminalis species [27] found $19150 \mathrm{mg} / \mathrm{kg}$ GAE total methanolextractable phenolic compounds, in frozen fruits.

Oven-drying of Pyracantha species fruits led to a $50-60.86 \%$ loss of phenolic compounds (Fig. 4), to $17247-24782 \mathrm{mg} / \mathrm{kg}$ GAE (maximum also in „Red Column”). The studies emphasize that the percentage drop in total phenolic content, for freeze-dried fruits, is highly variable, ranging from $10 \%$ to $50 \%$ [15, 28-32].

Total antioxidant capacity (TEAC) of hydroalcoholic fruits extracts was reported according to the ACL procedure, quantified by comparison with Trolox ${ }^{\circledR}$ standard substance. The results are expressed in nmol/vol. sample, Trolox equivalent units, according to Table 2.

Table 2. Total antioxidant capacity (TEAC) of Pyracantha coccinea fruits varieties hydroalcoholic extracts

\begin{tabular}{|c|c|c|c|c|c|c|}
\hline No. & Sample Type & $\begin{array}{l}\text { Extraction time } \\
\quad \text { (days) }\end{array}$ & $\begin{array}{c}\text { Working } \\
\text { volume }(\mu \mathrm{L})\end{array}$ & $\begin{array}{l}\text { Analysis time } \\
\quad(\mathrm{sec} .)\end{array}$ & $\begin{array}{l}\text { Free radicals } \\
\text { Max. } \\
\text { Inhibition }\end{array}$ & $\begin{array}{l}\text { Quantity means } \\
\text { (TEAC) } \\
\text { ( } \mu \text { mol equiv. } \\
\text { Trolox/g tissue) }\end{array}$ \\
\hline 1. & $\begin{array}{c}\text { Pyracantha coccinea „Orange } \\
\text { Glow”, dried, } 1 \% \text { in ethyl alcohol } \\
40 \%\end{array}$ & 12 & 10 & 120 & 0.650 & 27.46 \\
\hline 2. & $\begin{array}{l}\text { Pyracantha coccinea „Orange } \\
\text { Glow”, frozen, } 1 \% \text { in ethyl } \\
\text { alcohol } 40 \%\end{array}$ & 12 & 10 & 120 & 0.546 & $\begin{array}{c}24.70 \\
(123.50 \mathrm{DW})\end{array}$ \\
\hline 3. & $\begin{array}{l}\text { Pyracantha coccinea „Red } \\
\text { Column”, dried, } 1 \% \text { in ethyl } \\
\text { alcohol } 40 \%\end{array}$ & 12 & 10 & 120 & 0.671 & 27.96 \\
\hline 4. & $\begin{array}{c}\text { Pyracantha coccinea „Red } \\
\text { Column”, frozen, } 1 \% \text { in ethyl } \\
\text { alcohol } 40 \% \\
\end{array}$ & 12 & 10 & 120 & 0.429 & $\begin{array}{c}21.10 \\
(105.50 \mathrm{DW})\end{array}$ \\
\hline 5. & $\begin{array}{c}\text { Pyracantha coccinea ,Soleil } \\
\text { D’Or”, dried, } 1 \% \text { in ethyl alcohol } \\
40 \%\end{array}$ & 12 & 10 & 120 & 0.592 & 25.97 \\
\hline 6. & $\begin{array}{l}\text { Pyracantha coccinea „Soleil } \\
\text { D’Or”, frozen, } 1 \% \text { in ethyl } \\
\text { alcohol } 40 \%\end{array}$ & 12 & 10 & 120 & 0.560 & $\begin{array}{c}25.09 \\
(125.45 \mathrm{DW})\end{array}$ \\
\hline
\end{tabular}


For all fruit varieties, ethanol extracts of heat-dried pomes had the highest antioxidant activity. The highest values were found in 1\% extracts of dry „Red Column” fruits $(27.96 \mu \mathrm{mol} / \mathrm{g} \mathrm{FW})$; the lowest value was determined for frozen fruits extract of the same cultivar $(21.10 \mu \mathrm{mol} / \mathrm{g} F W)$. A high antioxidant activity was also determined in hydroalcoholic extracts of dried „Orange Glow” pomes $(27.46 \mu \mathrm{mol} / \mathrm{g} \mathrm{FW})$.

However, when transformed in dry weight values, differences become significant in favour of fresh frozen fruits. With a registered value of $125.45 \mu \mathrm{mol} / \mathrm{g} \mathrm{FW}$, „Soleil D'Or” pomes had the highest antioxidant activity.

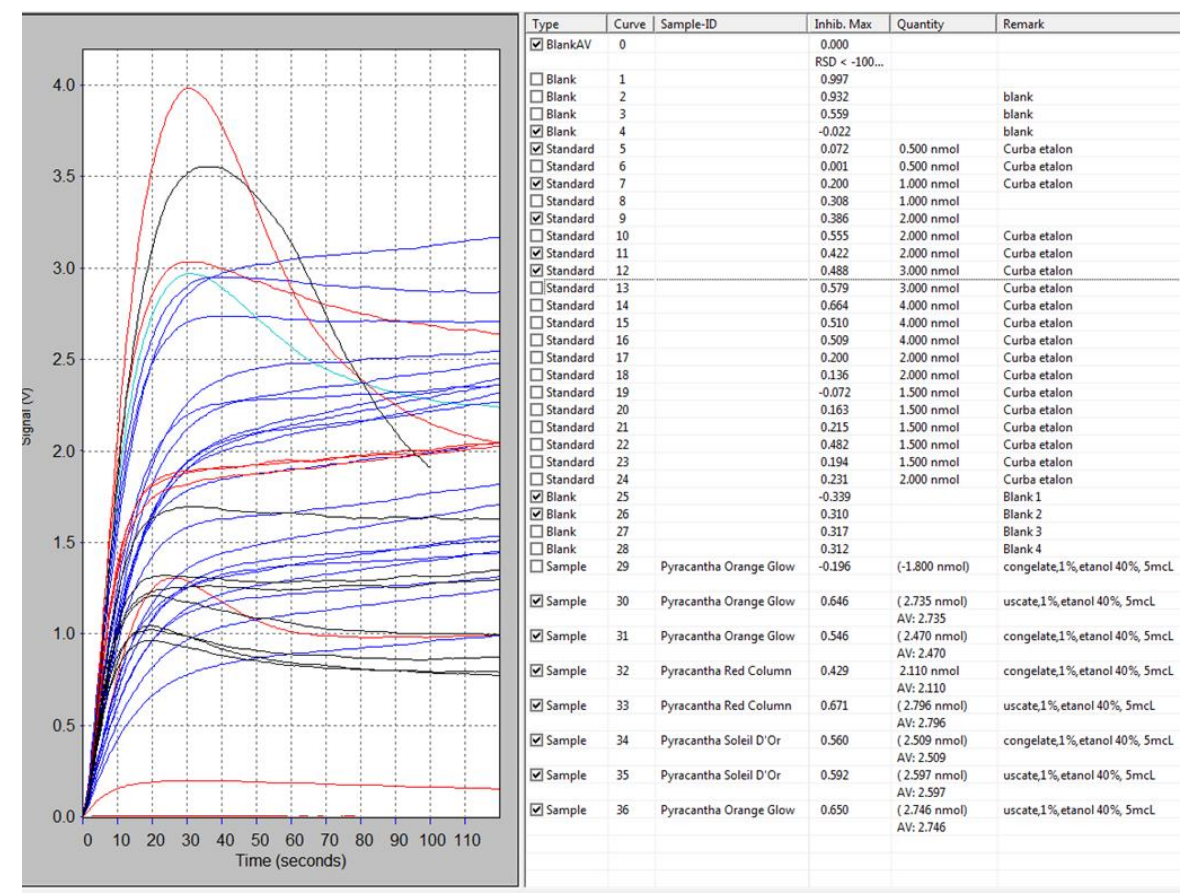

Figure 6. ACL procedure curves for Pyracantha coccinea species fruits extracts

For comparison, 13.00 - $32.98 \mu \mathrm{mol}$ Trolox equivalent/g were found in extracts of air-dried fruits of Pyracantha crenulata [14], while $49.00-476.00 \mu \mathrm{mol}$ Trolox equivalent/g were determined in lyophilized fruits various domestic Sorbus species cultivars [6].

\section{Conclusions}

The fruits of Pyracantha coccinea M. Roem. fruits have shown a carotenoid and phenolic content comparable to or higher than some wild or cultured relatives (including rowans or the medicinal plant Pyracantha crenulata). While the „Soleil d'Or” cultivar had the highest concentration of carotenoids $(545 \mathrm{mg} / \mathrm{kg})$ and flavonoids (4954 mg/kg) in fresh frozen fruits, ,Red Column”, closely followed by "Orange Glow", had the highest overall phenolic content (63320 mg/kg GAE).

While dry fruit ethanolic extracts had the highest antioxidant activity (up to 27.96 and 27.46 $\mu \mathrm{mol} / \mathrm{g} \mathrm{FW}$, in „Red Column”, respectively, „Orange Glow” cultivars), considering the initial dry biomass, the antioxidant activity per dry biomass of fruit pulp was maximal in fresh fruits, with 105.50 - $125.45 \mu \mathrm{mol} / \mathrm{g}$ DW (highest value in „Soleil D'Or” pomes).

Heat-drying had a negative effect on carotenoid and phenolic concentration, causing an average drop of 59\% and 55\%, respectively, and an irregular behaviour of flavonoid content. It also led to a $73.50-79.30 \%$ decrease in antioxidant activity per unit of fruit dry weight. This would imply that alternative means for processing and storage of mature firethorn fruits are needed in order to preserve their bioactive properties. 
Acknowledgement. This work was supported by a grant of the Romanian Ministry of Research and Innovation, CCCDI - UEFISCDI, project number PN-III-P1-1.2-PCCDI-2017-0689 /P1. „Lib2Life Revitalizarea bibliotecilor si a patrimoniului cultural prin tehnologii avansate" within PNCDI III

\section{References}

1.AKGUC, N, OZYIGIT, I.I., YARCI, C., Pak. J. Bot., 40, no. 4, 2008, p. 1767.

2.KARAISMAILOGLU, M.C., Turk. J. Life Sci., 2, no. 1, 2017, p. 110.

3.SULTANA, S., ALI, M., MIR, S.R., J. Pharm. Biol. Sci., 5, no. 3, 2017, p. 91.

4.BUTNARIU, M., SARAC, I., PENTEA, M., SAMFIRA, I., NEGREA, A., MOTOC, M., BUZATU, A.R., CIOPEC, M., Rev. Chim., 67, (3), 2016, p. 503.

5.KIVRAK, I, KIVRAK, S., Austin J. Nutr. Food Sci., 2, no. 8, 2014, p. 1043.

6.ZYMONE, K., RAUDONE, L., RAUDONIS, R., MARKSA, M., IVANAUSKAS, L., JANULIS, V., Molecules, 23, 2018, p. 2593.

7.POPOVICIU, D.R., NEGREANU-PIRJOL, T., MICLAUS, L.S., Rev. Chim., 68, (1), 2017, 40.

8.LICHTENTHALER, H.K., BUSCHMANN, C., Curr. Protoc. Food Anal. Chem., 2001, F4.3.1. p.1.

9.SZABO, I., VONHAZ, G., FODOR, A., BUNGAU, S., TIT, D.M., Analele Universitatii din Oradea, Fascicula Protectia Mediului, 18, 2012, p. 73.

10.STANKOVIC, M.S. Kragujevac J. Sci., 33, 2011, p. 63.

11.PALlAG, A., JURCA, T., SIRBU, V., HONIGES, A., JURCA, C., Rev. Chim. (Bucharest), 69, nr. 2, 2018, p. 445.

12.POPOV, I., LEWIN, G., Methods in Enzymology, 300, Part B, Oxidants and Antioxidants, Ed. Lester Packer, Academic Press, New York, 1999, p. 437.

13.ZECHMEISTER, L. SCHROEDER, W.A., J. Biol. Chem., 144, 1942, p. 315.

14.PAL, R.S., KUMAR, R.A., AGRAWAL P.K., BHATT, J.C., Int. J. Pharm. Bio. Sci., 4, no. 2., 2013, p 113.

15.SHOFIAN, N.M., HAMID, A.A., OSMAN, A., SAARI, N. ANWAR, F., DEK, M.S.P., HAIRUDDIN, M.R., Int. J. Mol. Sci., 12, no. 7, 2011, p. 4678-4692.

16.LEONG, S.Y., OEY, I, Food Chem., 133, no. 4, 2012, p. 1577-1587.

17.MOHAMED, S.A., SOKKAR, N.M., EL-GINDI, O., ALI, Z.Y., ALFISHAWY, I.M., Life Sci. J., 9, no. 2, 2012, p. 394.

18.LIU, X., JIA, J., JING, X., LI, G., J. Chem. (Hindawi), 2018, DOI: 10.1155/2018/4619768.

19.LACATUSU, I., BADEA, N., MURARIU, A., OPREA, O., BOJIN, D., MEGHEA, A., Soft Materials, 11, no. 1, 2013, p.75

20.MALAERU, T., PATROI, E.A., MARINESCU, V., OPREA, O., PATROI, D., MORARI, C., MANTA, E., GEORGESCU, G., Rev. Chim., 70, (2), 2019, 459.

21.NEGREANU-PIRJOL, B.-S., NEGREANU-PIRJOL, T., SIRBU, R., POPOVICIU, D.R., Rev. Chim., 70, (2), 2019, 602.

22.NICULAE, G., BADEA, N., MEGHEA, A., OPREA, O., LACATUSU, I., Photochemistry and Photobiology, 89, no. 5, 2013, p. 1085

23.MAJIĆ, B., ŠOLA, I., LIKIC, S., JURANOVIC, CINDRIC, I., RUSAK, G., Food Technol. Biotechnol., 53, no. 4, 2015, p. 463.

24.RAUDONIS, R., RAUDONĖ, L., GAIVELYTE, K, VISKELIS, P., JANULIS, V., Nat. Prod. Res., 28, no. 16, 2014, DOI: 10.1080/14786419.2014.895727.

25.NEGREANU-PIRJOL, T., NEGREANU-PIRJOL, B.-S., POPESCU, A., BRATU, M.M., UDREA, M., BUSURICU, F., Journal of Environmental Protection and Ecology, 15, no. 3, 2014, p. 1139 1148 .

26.NEGREANU-PIRJOL, B.-S., NEGREANU-PIRJOL, T., BRATU, M., POPESCU, A., RONCEA, F., MIRESAN, H., JURJA, S., PARASCHIV, G.M., $14^{\text {th }}$ International Multidisciplinary Scientific GeoConferences „Surveying Geology \& mining Ecology Management - SGEM 2014”, 17 - 26 
June 2014, Albena, Bulgaria, Conference Proceedings, Vol. I, Section: Advances in Biotechnology, p. 239 - 244, DOI: 10.5593/sgem2014B61.

27.HASBAL, G., YILMAZ-OZDEN, T., CAN, A., J. Food Drug Anal, 23, no. 1, 2015, p.57

28.MARIN, D.B., CIOANCA, O., APOSTU, M., TUCHILUS, C.G., MIRCEA, C., ROBU, S., TUTUNARU, D., CORCIOVA, A., HANCIANU, M., Rev. Chim., 70, (7), 2019, 2519

29.RADUlESCU, M., FICAI, D., OPREA, O., FICAI, A., ANDRONESCU, E., HOLBAN, A.M., Current Pharmaceutical Biotechnology, 16, no. 2, 2015, p. 128

30.LACATUSU, I., BADEA, N., BADEA, G., OPREA, O., MIHAILA, M.A., KAYA, D.A., STAN, R., MEGHEA, A., Materials Science and Engineering C, 56, 2015, p. 88

31.STAN, R.L., SEVASTRE, B., HANGAN, A.C., BOTA, S., HANGANU, D., IONESCU, C.M.L., POPOVICI, H., SEVASTRE-BERGHIAN, A.C., DREANCA, A., VICAS, L.G., Rev. Chim., 70, (6), 2019, 1903.

32.POPOVICIU, D.R., NEGREANU-PIRJOL, T., MOTELICA, L., NEGREANU-PIRJOL, B.-S., Rev. Chim., 71, (3), 2020, 136

Manuscript received: 20.08.2019 